Article

\title{
Soil Solarization and Calcium Cyanamide Affect Plant Vigor, Yield, Nutritional Traits, and Nutraceutical Compounds of Strawberry Grown in a Protected Cultivation System
}

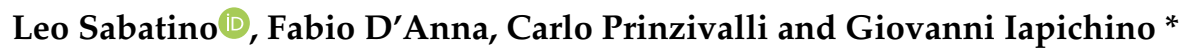 \\ Dipartimento Scienze Agrarie, Alimentari e Forestali, Università di Palermo, Viale delle Scienze, \\ 90128 Palermo, Italy \\ * Correspondence: giovanni.iapichino@unipa.it; Tel.: +39-091-2386-2215
}

Received: 12 August 2019; Accepted: 3 September 2019; Published: 5 September 2019

check for updates

\begin{abstract}
Soil solarization is a hydrothermal procedure of disinfesting soil of soilborne diseases and pests. Solarization can be combined with many other chemical or non-chemical alternatives to afford integrated pest and diseases management or improve plant yield. Calcium cyanamide $\left(\mathrm{CaCN}_{2}\right)$ is a fertilizer used in agriculture sector and is also effective in suppressing soilborne pathogens. The present study assessed the influences of different pre-plant $\mathrm{CaCN}_{2}$ dosages on strawberry grown on solarized or non-solarized soil. Soil solarization and $500 \mathrm{~kg} \mathrm{ha}^{-1} \mathrm{CaCN}_{2}$ significantly increased early marketable yield by $105.3 \%$, total marketable yield by $53.0 \%$ and firmness by $3.0 \%$, respectively compared with the control (no solarization $\times 0 \mathrm{~kg} \mathrm{ha}^{-1}$ of $\mathrm{CaCN}_{2}$ ). Exposing solarized plots to $\mathrm{CaCN}_{2}$ at $1000 \mathrm{~kg} \mathrm{ha}^{-1}$ significantly increased fruit ascorbic acid content by $77.5 \%$ and phenolic content by $13.3 \%$ compared with fruits from control plants. Overall, plants grown on solarized soil performed better than those cultivated on no-solarized plots. Plants grown on soil treated with a dosage of 500 or $1000 \mathrm{~kg} \mathrm{ha}^{-1} \mathrm{CaCN}_{2}$ increased plant height, number of shoots plant ${ }^{-1}$, number of leaves plant ${ }^{-1}$, root collar diameter, plant visual quality, anthocyanins, and antioxidant capacity compared to control plants. Fruits from plants grown on soil exposed to $\mathrm{CaCN}_{2}$ with a dosage of 500 and $1000 \mathrm{~kg} \mathrm{ha}^{-1}$ showed a lower $\mathrm{N}$ fruit content (5.4 and 19.5\%, respectively) than control plants (non-treated control).
\end{abstract}

Keywords: Fragaria $\times$ ananassa; pre-plant treatments; $\mathrm{N}$ fruit accumulation; $\mathrm{CaCN}_{2}$; crop performance; fruit quality

\section{Introduction}

Strawberry Fragaria $\times$ ananassa Duch. $(2 n=8 x=56)$ is an economically important fruit crop belonging to the Rosaceae family. It is one of the most popular fruits growing in the Northern hemisphere in temperate and sub-temperate environment [1]. Sicily differs from other strawberry production zones due toearlier fruit ripening. This earliness is enhanced by the use of fresh plants, which, compared to the cold-stored plants used in the past, have expanded the harvest window from December to May and provided fruits of higher quality [2,3]. The berries, which are rich in bioactive phytochemicals, especially phenolic compounds with high antioxidant capacity, are beneficial for human health [4] as a part of daily diet.

The intensive cropping systems, adopted generally for strawberry production under protected cultivation, have determined an upsurge of biotic detrimental factors [5] that can negatively affect yield and strawberry fruit quality [3]. These unfavorable factors caused an enlarge in the use of input factors, such as chemical fertilizer and pesticides, that in turn have led to ecological and health concerns. Subsequent to the ban of methyl bromide, since 2005 in developed countries and 
from 2015 in developing countries [6], the need for more environmentally friendly plant production systems occurred.

Soil solarization is a disinfection technique that employs solar radiation during summer months to increase the soil temperature under a polyethylene tarped field in which the soil-water content is brought to field capacity [7]. Soil solarization produces, for an extended period of time, soil temperatures between 37 and $55{ }^{\circ} \mathrm{C}$ at a depth of $15 \mathrm{~cm}$, which are deleterious to soilborne plant pathogenic organisms [8] such as soilborne fungi (Verticillium dahliae, Phytophthora fragariae, P. cactorum, Rhizoctonia spp., Pythium spp., Fusarium spp.) and virus-transmitting nematodes [9]. High temperatures $\left(55^{\circ} \mathrm{C}\right)$ can also reduce the risk of spreading of highly infectious viruses such as Pepino mosaic virus, released in the soil from the seeds and the roots of infected plants [10,11]. Kodama and Fukai [12] and D'Anna et al. [2], report that in soil used for strawberry cultivation soil solarization represents a good alternative to Methyl Bromide both for pathogens control and improving plant performance. Solarization represents an attractive practice for strawberry cultivation in Sicily and in the Mediterranean areas since the crop is usually grown as an annual, with a summer fallow period (best for solarization) followed by a fall planting through clear plastic mulch.

Calcium cyanamide $\left(\mathrm{CaCN}_{2}\right)$ is very well known as a fertilizer used in the agriculture sector. It can improve the soil, prevent soil acidification, and increase yield and fruit quality [13]. Bletsos [14] demonstrated that $\mathrm{CaCN}_{2}$ use as a soil fumigant for controlling soilborne diseases is effective in suppressing clubroot disease in cabbage and fusarium wilt in cucumber and melon. Furthermore, soil sterilization with $\mathrm{CaCN}_{2}$ has positive influences on growth, production, and fusarium wilt control in melon compared with methyl bromide soil fumigation [14]. Zhu et al. [15] demonstrated that $\mathrm{CaCN}_{2}$ can successfully control spinach rhizoctonia rot and strawberry fusarium wilt and eradicate certain pests and viruses in the soil.

Solarization and $\mathrm{CaCN}_{2}$ fumigation are simple, efficient and practical methods for strawberry production. However, since plant response to solarization and $\mathrm{CaCN}_{2}$ fumigation are affected by genotype and growing conditions, a specific study isnecessary to assess methods and doses. To the best of our knowledge, the literature lacks information on the interaction between solarization and $\mathrm{CaCN}_{2}$ dosage in strawberry and on its effects on fruit quantitative and qualitative characteristics. Starting from the above premises, the objective of our research was to evaluate the interactive effect of solarization and $\mathrm{CaCN}_{2}$ dosage on growth, development, yield, and qualitative traits of an established strawberry cultivar in a representative Sicilian production area.

\section{Materials and Methods}

\subsection{Crop System and Treatments}

The research was carried out for two years from June 2016 to May 2018 in the experimental farm of the Department Agriculture, Food and Forestry Sciences of Palermo (SAAF), at Marsala, Trapani Province (longitude $12^{\circ} 26^{\prime} \mathrm{E}$, latitude $37^{\circ} 47^{\prime} \mathrm{N}$, altitude $37 \mathrm{~m}$ ) on the northwestern coast of Sicily (Italy). The preceding crop was strawberry. "Florida Fortuna" cultivar was transplanted by using the conventional winter planting system for protected cultivation [16]. The trial was conducted under multiple tunnels. The soil of the experimental field was basically derived from transformation of the typically fertile Sicilian "sciare" soils, mainly made up of sand $(<80 \%)$ at $\mathrm{pH} 8.5$, high activity limestone at $8.8 \%$ and richly endowed with exchangeable $\mathrm{K}_{2} \mathrm{O}(660 \mathrm{ppm})$, phosphorous (68 ppm), total nitrogen $(2 \%)$, and organic matter from exhausted distillery marc (10 t/ha). Previous to transplant, half of the experimental field was solarized with a green polyethylene (PE) film $(0.05 \mathrm{~mm})$ for 75 days starting from 15 June 2016 and 15 June 2017. Throughout solarization, soil temperature was measured at $15 \mathrm{~cm}$ depth and recorded every $60 \mathrm{~min}$, using a Testo 175-T2 data logger (Farnell, Milan, Italy) (Figure 1). 


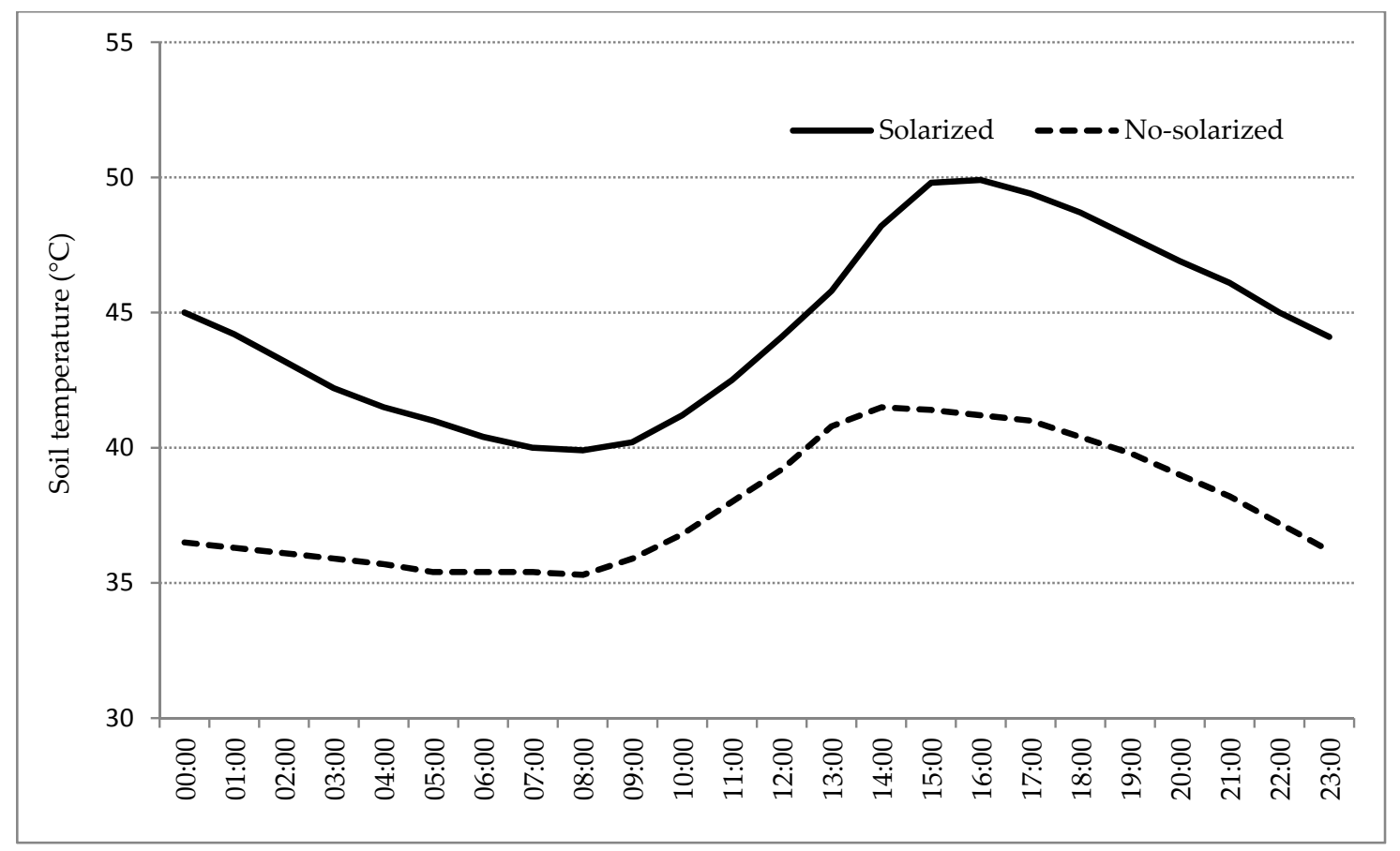

Figure 1. Average hourly soil temperature in solarized and no-solarized plots.

The same film was maintained on the soil as mulching during strawberry cultivation. As a second treatment factor, on 14 June 2016 and 14 June 2017, three different doses of calcium cyanamide $\left(\mathrm{CaCN}_{2}\right)\left(0,500\right.$, or $1000 \mathrm{~kg} \mathrm{ha}^{-1}$, based on our preliminary unpublished study) were supplied in both no-solarized and solarized plots, respectively. The application of granular $\mathrm{CaCN}_{2}(19.8 \%$ of N) (Perlka; AlzChem, Trostberg, Germany) was performed by broadcasting on the whole plot surface and subsequently incorporating into the soil about $10 \mathrm{~cm}$ deep. Freshly containerized plants were transplanted on 15th September 2016 and 2017 in twin rows at a density of eight plants $\mathrm{m}^{-2}$. All cultural practices recommended for strawberry cultivation were adopted uniformly according to crop necessities. Fertigations provided an overall $200 \mathrm{~kg} \mathrm{ha}^{-1}$ of $\mathrm{N}$ (including the nitrogen supplied via $\mathrm{CaCN}_{2}$ ), $150 \mathrm{~kg} \mathrm{ha}^{-1}$ of $\mathrm{P}_{2} \mathrm{O}_{5}, 300 \mathrm{~kg} \mathrm{ha}^{-1}$ of $\mathrm{K}_{2} \mathrm{O}$ and $60 \mathrm{~kg} \mathrm{ha}^{-1}$ of iron chelate. Thus, all plots received the same amount of $\mathrm{N}, \mathrm{P}_{2} \mathrm{O}_{5}, \mathrm{~K}_{2} \mathrm{O}$, and iron chelate. Nitrogen supplied via fertigation was in the form of $\mathrm{NO}_{3}{ }^{-}$. The tunnels were covered in the second half of November with $120 \mu \mathrm{m}$ thick clear PE plus ethylene vinyl acetate (EVA).

The two solarization treatments (solarized soil vs non-solarized soil) were combined with the three $\mathrm{CaCN}_{2}$ treatments in a two factorial experimental design rendering six treatments. Each treatment was replicated three times and contained 10 plants. Thus, the total number of strawberry plants was 180.

Meteorological data for both growing seasons (2016-2017 and 2017-2018) were recorded and provided by the meteorological station of the experimental farm of the Department SAAF. Average, maximum, and minimum daily temperature during the plant growing period was observed (Figures 2 and 3). 


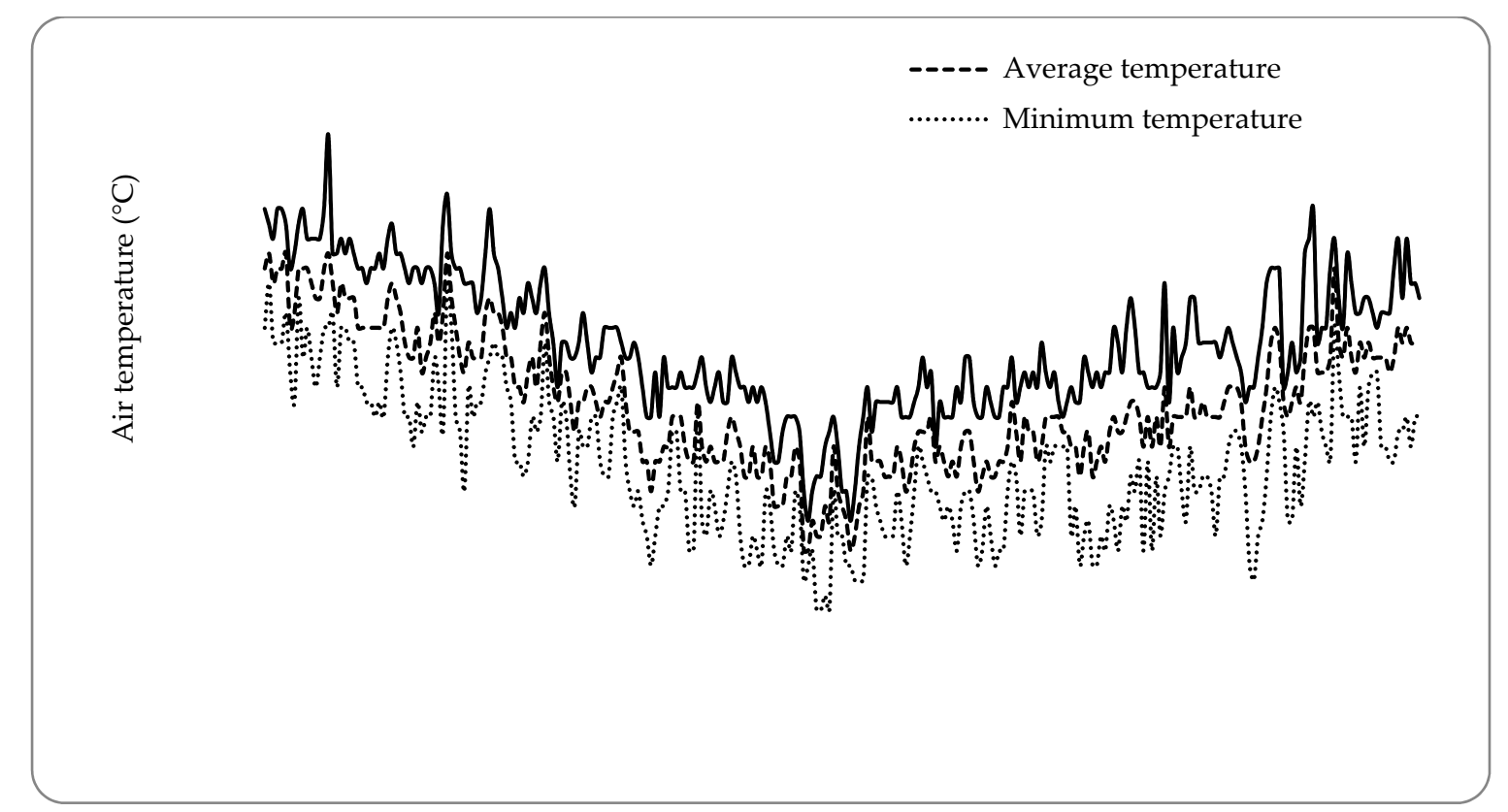

Figure 2. Daily average, minimum and maximum air temperature at Marsala, Trapani Province (longitude $12^{\circ} 26^{\prime} \mathrm{E}$, latitude $37^{\circ} 47^{\prime} \mathrm{N}$, altitude $37 \mathrm{~m}$ ) during the first experiment (2016-2017).

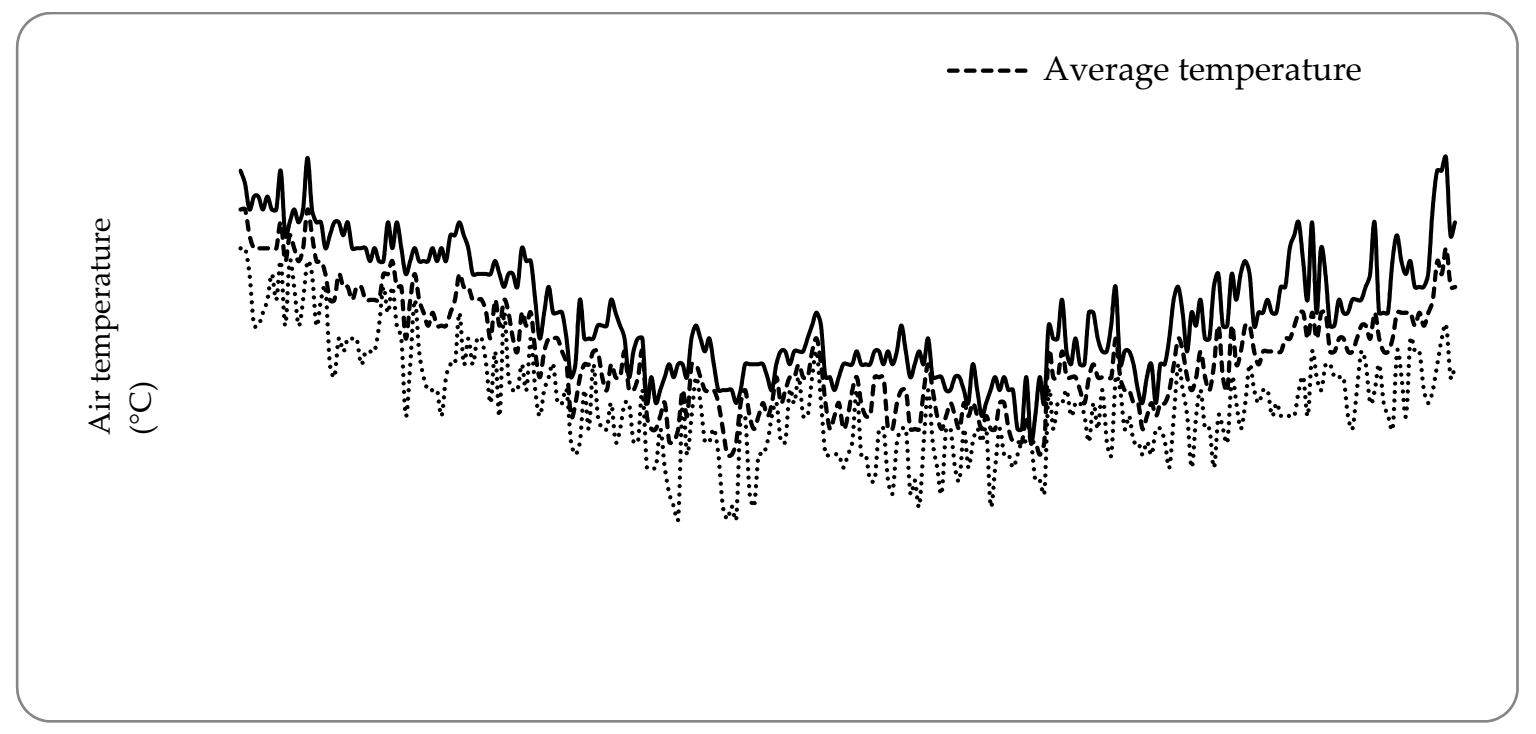

Figure 3. Daily average, minimum and maximum air temperature at Marsala, Trapani Province (longitude $12^{\circ} 26^{\prime} \mathrm{E}$, latitude $37^{\circ} 47^{\prime} \mathrm{N}$, altitude $37 \mathrm{~m}$ ) during the second experiment (2017-2018).

\subsection{Measurements and Analysis}

Fruit yield data were recorded monthly from November to May. Total fruit yield was also calculated. Monthly and total fruit yield was intended by taking all the harvested fruit on each picking, and thereafter, fruits that were free from malformation and Botrytis rot symptoms were sorted out to calculate the marketable fruit yield.

At the beginning of the first harvest (55 days after transplanting), plant height, number of shoots plant $^{-1}$, number of leaves plant ${ }^{-1}$ and root collar diameter were recorded. At the end of the cycle (end of May) the plant visual quality was also scored on a 9 to 1 continuous scale, where 9 refers to excellent appearance, 7 to good, 5 to fair (plant that produces fruits at limit of marketability), 3 to fair (plant that produces fruits usable but not saleable), and 1 to plant seriously damaged. 
Sampling for the quality analysis of the fruits was carried out as described by Sabatino et al. [16]. Therefore, 10 representative commercially mature fruits for each replication were used. Color $\left(\mathrm{L}^{*}, \mathrm{a}^{*}\right.$, and $\mathrm{b}^{*}$ parameters-CIELab) was measured on two opposite point of strawberry fruit skin (equatorial zone) by a colorimeter (Chroma-meter CR-400, Minolta Corporation, Ltd., Osaka, Japan). Fruit firmness was determined by measuring its resistance to the plunger of a digital penetrometer (Trsnc, Italy). Each fruit was subjected to a compression in two opposite point in the equatorial part using a $6 \mathrm{~mm}$ diameter stainless steel cylinder probe. The mean peak force was calculated in Newton (N). Sample of the fruit pulp were squeezed by hand with a garlic squeezer. The juice was filtered and total soluble solids (TSS) was measured using a digital refractometer (MTD-045nD, Three-In-One Enterprises Co. Ltd., New Taipei, Taiwan).Titratable acidity (TA) was determined using $10 \mathrm{~g}$ aliquots of strawberry fruits poured in $50 \mathrm{~mL}$ of distilled water and titrated with $0.1 \mathrm{~N}$ $\mathrm{NaOH}$ to an end-point of $\mathrm{pH}$ 8.1. TA was expressed as percentage of citric acid and was calculated using the method reported by Han et al. [17]. Fruit nitrogen content $(\mathrm{N})$ was obtained from the Kjeldahl method. Ascorbic acid content was determined reflectometrically using a Reflectometer RQflex10 Reflectoquant (Sigma-Aldrich, Saint Louis, MO, USA), and the Reflectoquant Ascorbic Acid Test strips. One gram of fruit juice was dissolved in distilled water, maked up to $10 \mathrm{~mL}$, and mixed. Then dipped appropriate test strip into the sample and inserted it into the meter. Results were expressed as $\mathrm{mg}$ of ascorbic acid per $\mathrm{L}$ fresh weight.

Total phenolics was measured by using $2 \mathrm{~g}$ of each sample was weighed out and extracted with $50 \mathrm{~mL}$ of methanol. The extraction was conducted under stirring for $60 \mathrm{~min}$ at $60^{\circ} \mathrm{C}$. The mixture was filtered through filter paper (Whatman No. 3; Merck, Darmstadt, Germany), filled in a $50 \mathrm{~mL}$ volumetric flask and allowed to set in the dark until analysis. Total phenolic content was determined according to the Folin-Ciocalteu (FC) method [18] with slight modifications. The standard or sample extract $(100 \mu \mathrm{L})$ (triplicate) was mixed with $0.4 \mathrm{~mL}$ FC reagent. After 3 min reaction $0.8 \mathrm{~mL}$ of $10 \% \mathrm{Na}_{2} \mathrm{CO}_{3}$ was added. The tubes were allowed to stand for $30 \mathrm{~min}$ at ambient temperature, and the absorption was measured at $765 \mathrm{~nm}$ using a spectrophotometer (CELL, model CE 1020; Cecil Instruments Ltd., Cambridge, England). Gallic acid was used as calibration standard, and the results were calculated as gallic acid equivalent (GAE) ( $\mathrm{mg} / 100 \mathrm{~g}$ dry weight basis).

Total anthocyanins were obtained by using the fruit extract as reported by Rabino and Mancinell [19]. About $2 \mathrm{~g}$ (triplicate) of each sample was weighed out and extracted with $50 \mathrm{~mL}$ of solvent containing hydrochloric acid ethanol mixture (95\% ethanol, $1.5 \mathrm{~N} \mathrm{HCl}(85 / 15)$ ), the mixture was stored overnight at $4{ }^{\circ} \mathrm{C}$, then filtered out using Whatman No. 3 filter paper. After extraction of anthocyanins with acidified ethanol, the absorbance of the extracts was measured using a spectrophotometer (CELL, model CE 1020) at 530 and $657 \mathrm{~nm}$. Using formula A = (A $530-0.25 \mathrm{~A}$ $657)$ to compensate the contribution of chlorophyll and its degraded products to the absorption at $530 \mathrm{~nm}$. The anthocyanins content was expressed as $\mathrm{mg}$ of Cya-3-glucoside equivalent per $100 \mathrm{~g}$ of dry sample weight.

Radical-scavenging activity of 1,1-diphenyl-2-picrylhydrazyl radical (DPPH) of fruit samples was measured in terms of their radical-scavenging ability (RSA), using the DPPH method [20,21]. The percentage decrease in absorbance was recorded for each sample, and percentage quenching of DPPH radical was calculated on the basis of the observed decrease in absorbance according to the formula

$$
\% \text { Inhibition }=\left[\left(\mathrm{A}_{0}-\mathrm{A}_{1}\right) / \mathrm{A}_{0}\right] \times 100
$$

where $\mathrm{A}_{0}$ is the absorbance value of the DPPH blank solution and $\mathrm{A}_{1}$ is the absorbance value of the sample solution. 


\subsection{Statistical Analysis}

The statistical analysis was carried out with the statistical analysis system SPSS software package version 14.0 (StatSoft, Inc., Chicago, IL, USA) using the General Linear Model (GLM). The three calcium cyanamide $\left(\mathrm{CaCN}_{2}\right)$ doses were combined with the solarization treatment (solarization or no-solarization) in a two-factorial split-plot experimental design. The impact of the different treatments was evaluated by applying two-factorial ANOVA, whereas multiple comparisons of means were performed by applying the Tukey Honestly Significant Difference (HSD) test. For data expressed in percentage, the $\arcsin$ transformation before ANOVA analysis $\left(\varnothing=\arcsin (\mathrm{p} / 100)^{1 / 2}\right)$ was applied.

\section{Results}

\subsection{Strawberry Yield and Morphological Traits}

For the monthly marketable and total yield, a significant interaction was found between soil solarization and $\mathrm{CaCN}_{2}$ pre-plant treatment (Table 1).

November marketable yield on no-solarized soil treated with 500 and $1000 \mathrm{~kg} \mathrm{ha}^{-1}$ of $\mathrm{CaCN}_{2}$ and in solarized soil treated with 0,500 , and $1000 \mathrm{~kg} \mathrm{ha}^{-1}$ of $\mathrm{CaCN}_{2}$ were significantly higher than those in control plants (strawberry plants grown on no-solarized soil treated with $0 \mathrm{~kg} \mathrm{ha}^{-1}$ of $\mathrm{CaCN}_{2}$ ) (Table 1).

Plants grown on solarized soil and subjected to $\mathrm{CaCN}_{2}$ treatment with a dosage of $500 \mathrm{~kg} \mathrm{ha}^{-1}$ had the highest marketable yield in December, followed by plants cultivated on solarized soil and treated with $1000 \mathrm{~kg} \mathrm{ha}^{-1}$ of $\mathrm{CaCN}_{2}$ (Table 1). Control plants (no solarization $\times 0 \mathrm{~kg} \mathrm{ha}^{-1}$ of $\mathrm{CaCN}_{2}$ ) displayed the lowest monthly marketable yield.

Applying a $\mathrm{CaCN}_{2}$ dosage of $500 \mathrm{~kg} \mathrm{ha}^{-1}$ to strawberry grown on no-solarized soil resulted in the highest monthly marketable yield in January, while the combination solarization $\times 1000 \mathrm{~kg} \mathrm{ha}^{-1} \mathrm{CaCN}_{2}$ treatment gave the lowest marketable yield (Table 1).

The treatment solarization $\times 500 \mathrm{~kg} \mathrm{ha}^{-1}$ of $\mathrm{CaCN}_{2}$ produced the highest marketable yield in February, March, April, and May, whereas the control plants revealed the lowest yield performance in terms of monthly production (Table 1 ).

Plants grown on solarized soil with $500 \mathrm{~kg} \mathrm{ha}^{-1}$ of $\mathrm{CaCN}_{2}$ showed the highest total yield plant ${ }^{-1}$, followed by those cultivated on solarized soil with $1000 \mathrm{~kg} \mathrm{ha}^{-1}$ of $\mathrm{CaCN}_{2}$. Control plants gave the lowest total yield plant ${ }^{-1}$ (Table 1). 
Table 1. Effect of soil solarization and calcium cyanamide $\left(\mathrm{CaCN}_{2}\right)$ pre-plant treatment on monthly and total marketable yield of strawberry grown in a protected cultivation system.

\begin{tabular}{|c|c|c|c|c|c|c|c|c|c|c|c|c|c|c|c|c|}
\hline \multirow{2}{*}{ Treatments } & \multicolumn{16}{|c|}{ Monthly Marketable Yield (g plant ${ }^{-1}$ ) } \\
\hline & \multicolumn{2}{|c|}{ Nov. } & \multicolumn{2}{|c|}{ Dec. } & \multicolumn{2}{|c|}{ Jan. } & \multicolumn{2}{|c|}{ Feb. } & \multicolumn{2}{|c|}{ Mar. } & \multicolumn{2}{|c|}{ Apr. } & \multicolumn{2}{|c|}{ May } & \multicolumn{2}{|c|}{ Total } \\
\hline No Solarization $\times 0 \mathrm{~kg} \mathrm{ha}^{-1}$ of $\mathrm{CaCN}_{2}$ & 5.7 & $\mathrm{~b}$ & 22.0 & $\mathrm{e}$ & 30.0 & $\mathrm{~b}$ & 130.0 & $\mathrm{e}$ & 268.3 & e & 195.1 & $\mathrm{f}$ & 83.6 & $\mathrm{f}$ & 677.0 & $\mathrm{f}$ \\
\hline No Solarization $\times 500 \mathrm{~kg} \mathrm{ha}^{-1}$ of $\mathrm{CaCN}_{2}$ & 11.7 & a & 51.0 & $\mathrm{~d}$ & 33.7 & $\mathrm{a}$ & 154.0 & c & 354.0 & $\mathrm{~b}$ & 294.7 & $\mathrm{~d}$ & 126 & $\mathrm{~d}$ & 929.0 & $\mathrm{~d}$ \\
\hline No Solarization $\times 1000 \mathrm{~kg} \mathrm{ha}^{-1}$ of $\mathrm{CaCN}_{2}$ & 10.0 & a & 50.3 & $\mathrm{~d}$ & 30.7 & $\mathrm{~b}$ & 145.0 & $\mathrm{~d}$ & 315.7 & $\mathrm{~d}$ & 278.1 & e & 119 & e & 858.0 & $\mathrm{e}$ \\
\hline Solarization $\times 0 \mathrm{~kg} \mathrm{ha}^{-1}$ of $\mathrm{CaCN}_{2}$ & 11.3 & a & 55.0 & c & 30.0 & $\mathrm{~b}$ & 173.3 & $\mathrm{~b}$ & 340.0 & c & 310.6 & c & 133 & c & 957.0 & c \\
\hline Solarization $\times 500 \mathrm{~kg} \mathrm{ha}^{-1}$ of $\mathrm{CaCN}_{2}$ & 11.7 & a & 71.3 & a & 22.0 & c & 182.7 & a & 366.0 & a & 341.1 & a & 146 & a & 1036.0 & a \\
\hline Solarization $\times 1000 \mathrm{~kg} \mathrm{ha}^{-1}$ of $\mathrm{CaCN}_{2}$ & 11.0 & a & 64.0 & $\mathrm{~b}$ & 24.7 & $\mathrm{~d}$ & 171.7 & $\mathrm{~b}$ & 360.7 & $\mathrm{a}$ & 319.9 & $\mathrm{~b}$ & 137 & $\mathrm{~b}$ & 989.3 & $\mathrm{~b}$ \\
\hline \multicolumn{17}{|l|}{ Significance } \\
\hline Solarization & \multicolumn{2}{|c|}{$* *$} & \multicolumn{2}{|c|}{$* * *$} & \multicolumn{2}{|c|}{$* * *$} & \multicolumn{2}{|c|}{$* * *$} & \multicolumn{2}{|c|}{$* * *$} & \multicolumn{2}{|c|}{$* * *$} & \multicolumn{2}{|c|}{$* * *$} & \multicolumn{2}{|c|}{$* * *$} \\
\hline Calcium cyanamide $\left(\mathrm{CaCN}_{2}\right)$ & \multicolumn{2}{|c|}{$* *$} & \multicolumn{2}{|c|}{$* * *$} & \multicolumn{2}{|c|}{ NS } & \multicolumn{2}{|c|}{$* * *$} & \multicolumn{2}{|c|}{$* * *$} & \multicolumn{2}{|c|}{$* * *$} & \multicolumn{2}{|c|}{$* * *$} & \multicolumn{2}{|c|}{$* * *$} \\
\hline Solarization $\times \mathrm{CaCN}_{2}$ & \multicolumn{2}{|c|}{ ** } & \multicolumn{2}{|c|}{$* * *$} & \multicolumn{2}{|c|}{$* *$} & \multicolumn{2}{|c|}{$* *$} & \multicolumn{2}{|c|}{$* * *$} & \multicolumn{2}{|c|}{$* * *$} & \multicolumn{2}{|c|}{ *** } & \multicolumn{2}{|c|}{$* * *$} \\
\hline
\end{tabular}

Data within a column followed by the same letter are not significantly different at $p \leq 0.05$ according to Tukey Honestly Significant Difference (HSD) Test. The significance is designated by asterisks as follows: ${ }^{* *}$ statistically significant differences at $p$-value below $0.01 ;{ }^{* * *}$ statistically significant differences at $p$-value below 0.001 ; NS, not significant. 
Regardless of the $\mathrm{CaCN}_{2}$ dosage, plants grown on solarized soil showed higher values in terms of plant height, number of shoots plant ${ }^{-1}$, number of leaves plant ${ }^{-1}$, root collar diameter and plant visual quality compared to the plants cultivated on no-solarized soil (Table 2).

Table 2. Effect of soil solarization and $\mathrm{CaCN}_{2}$ pre-plant treatment on plant height, number of shoots plant $^{-1}$, number of leaves plant ${ }^{-1}$, root collar diameter, and plant visual quality of strawberry grown in a protected cultivation system.

\begin{tabular}{|c|c|c|c|c|c|c|c|c|c|c|}
\hline \multirow{2}{*}{$\begin{array}{l}\text { Treatments } \\
\text { Solarization }\end{array}$} & \multicolumn{2}{|c|}{$\begin{array}{l}\text { Plant Height } \\
\text { (cm) }\end{array}$} & \multicolumn{2}{|c|}{$\begin{array}{l}\text { No. of Shoots } \\
\text { Plant }^{-1}\end{array}$} & \multicolumn{2}{|c|}{$\begin{array}{l}\text { No. of Leaves } \\
\text { Plant }^{-1}\end{array}$} & \multicolumn{2}{|c|}{$\begin{array}{c}\text { Root Collar } \\
\text { Diameter }(\mathrm{mm})\end{array}$} & \multicolumn{2}{|c|}{$\begin{array}{c}\text { Plant Visual } \\
\text { Quality }\end{array}$} \\
\hline & & & & & & & & & & \\
\hline No solarization & 18.5 & $\mathrm{~b}$ & 4.4 & $\mathrm{~b}$ & 29.2 & $\mathrm{~b}$ & 19.6 & $\mathrm{~b}$ & 6.3 & $\mathrm{~b}$ \\
\hline Solarization & 25.5 & $\mathrm{a}$ & 5.1 & $\mathrm{a}$ & 32.3 & a & 22.2 & a & 8.5 & a \\
\hline \multicolumn{11}{|l|}{ Calcium cyanamide dosage $\left(\mathrm{kg} \mathrm{ha}^{-1}\right)$} \\
\hline 0 & 15.8 & $\mathrm{c}$ & 3.9 & $\mathrm{~b}$ & 25.3 & $\mathrm{~b}$ & 16.3 & $\mathrm{c}$ & 5.8 & $\mathrm{~b}$ \\
\hline 500 & 23.4 & $\mathrm{~b}$ & 5.2 & $\mathrm{a}$ & 32.5 & $\mathrm{a}$ & 21.5 & $\mathrm{~b}$ & 8.2 & a \\
\hline 1000 & 27.8 & $\mathrm{a}$ & 5.3 & a & 35.0 & $\mathrm{a}$ & 24.8 & a & 8.2 & a \\
\hline \multicolumn{11}{|l|}{ Significance } \\
\hline Solarization & \multicolumn{2}{|c|}{$* * *$} & \multicolumn{2}{|c|}{$* * *$} & \multicolumn{2}{|c|}{$* *$} & \multicolumn{2}{|c|}{$* * *$} & \multicolumn{2}{|c|}{$* * *$} \\
\hline Calcium cyanamide $\left(\mathrm{CaCN}_{2}\right)$ & \multicolumn{2}{|c|}{$* * *$} & \multicolumn{2}{|c|}{$* * *$} & \multicolumn{2}{|c|}{$* * *$} & \multicolumn{2}{|c|}{$* * *$} & \multicolumn{2}{|c|}{$* * *$} \\
\hline Solarization $\times \mathrm{CaCN}_{2}$ & \multicolumn{2}{|c|}{ NS } & \multicolumn{2}{|c|}{ NS } & \multicolumn{2}{|c|}{ NS } & \multicolumn{2}{|c|}{ NS } & \multicolumn{2}{|c|}{ NS } \\
\hline
\end{tabular}

Data within a column followed by the same letter are not significantly different at $p \leq 0.05$ according to Tukey Honestly Significant Difference (HSD) Test. The significance is designated by asterisks as follows: ${ }^{* *}$ statistically significant differences at $p$-value below 0.01 ; ${ }^{* * *}$ statistically significant differences at $p$-value below 0.001 ; NS, not significant.

Irrespective of the solarization treatment, strawberries grown on soil treated with a dosage of $1000 \mathrm{~kg} \mathrm{ha}{ }^{-1}$ of $\mathrm{CaCN}_{2}$ revealed the highest values as regard the aforesaid traits. However, for number of shoots per plant ${ }^{-1}$, number of leaves plant ${ }^{-1}$, and plant visual quality, ANOVA analysis and mean separation did not show significant differences between plants cultivated on soil treated with $1000 \mathrm{~kg} \mathrm{ha}^{-1}$ of $\mathrm{CaCN}_{2}$ and those grown on soil treated with $500 \mathrm{~kg} \mathrm{ha}^{-1}$ of $\mathrm{CaCN}_{2}$. Plants cultivated with $0 \mathrm{~kg} \mathrm{ha}^{-1}$ of $\mathrm{CaCN}_{2}$ revealed the lowest values in terms of plant height, number of shoots plant ${ }^{-1}$, number of leaves plant ${ }^{-1}$, root collar diameter, and plant visual quality. No significant interaction was found between solarization and $\mathrm{CaCN}_{2}$ treatment for all plant growth parameters reported in Table 2.

\subsection{Nutritional and Nutraceutical Qualities}

ANOVA for TSS, firmness, ascorbic acid phenolic content, $\mathrm{a}^{*}$ color coordinate and $\mathrm{L}^{*}$ color coordinate showed a significant effect of the interaction solarization $\times \mathrm{CaCN}_{2}$ (Table 3).

Fruits from plants grown on no-solarized soil with a dosage of $500 \mathrm{~kg} \mathrm{ha}^{-2}$ of $\mathrm{CaCN}_{2}$ had the highest TSS value (Table 3), whereas fruits from control plants revealed the lowest one. Strawberry fruits from plants subjected to the treatments no-solarization $\times 1000 \mathrm{~kg} \mathrm{ha}^{-1}$ of $\mathrm{CaCN}_{2}$ and solarization $\times 500 \mathrm{~kg} \mathrm{ha}^{-1}$ of $\mathrm{CaCN}_{2}$ revealed the highest value in terms of firmness (Table 3), while control plants gave the softest fruits. However, solarization $\times 0$ and $\times 1000 \mathrm{~kg} \mathrm{ha}^{-1}$ of $\mathrm{CaCN}_{2}$ are comparable to no-solarization $\times 1000 \mathrm{~kg} \mathrm{ha}^{-1} \mathrm{CaCN}_{2}$ and solarization $\times 500 \mathrm{~kg} \mathrm{ha}^{-1} \mathrm{CaCN}_{2}$.

Fruits from plants grown on solarized soil with $1000 \mathrm{~kg} \mathrm{ha}^{-1}$ of $\mathrm{CaCN}_{2}$ provided the highest ascorbic acid content, followed by those from plants cultivated on solarized soil with $500 \mathrm{~kg} \mathrm{ha}^{-1}$ of $\mathrm{CaCN}_{2}$ (Table 3). Control plants had the lowest fruit ascorbic acid content. Data collected on fruit phenolic content supported the trend established for ascorbic acid content (Table 3). Fruits from plants cultivated on no-solarized plots and treated with a dosage of $500 \mathrm{~kg} \mathrm{ha}^{-1}$ of $\mathrm{CaCN}_{2}$ had the highest $\mathrm{a}^{*}$ color coordinated, followed by those from solarized plot and treated with $500 \mathrm{~kg} \mathrm{ha}^{-1} \mathrm{of} \mathrm{CaCN}_{2}$ (Table 3). Fruits from control plots had the lowest $a^{*}$ color coordinate. 
Table 3. Effect of soil solarization and $\mathrm{CaCN}_{2}$ pre-plant treatment on total soluble solids (TSS), firmness, ascorbic acid, phenolic content, $\mathrm{a}^{*}$, and $\mathrm{L}^{*}$ of strawberry grown in a protected cultivation system.

\begin{tabular}{|c|c|c|c|c|c|c|c|c|c|c|c|c|}
\hline \multirow{2}{*}{$\begin{array}{c}\text { Treatments } \\
\text { No Solarization } \times 0 \mathrm{~kg} \mathrm{ha}^{-1} \text { of } \mathrm{CaCN}_{2}\end{array}$} & \multicolumn{2}{|c|}{ TSS $\left(\right.$ Brix $\left.^{\circ}\right)$} & \multicolumn{2}{|c|}{ Firmness (N) } & \multicolumn{2}{|c|}{$\begin{array}{l}\text { Ascorbic Acid } \\
\left(\mathrm{mg} \mathrm{L}^{-1}\right)\end{array}$} & \multicolumn{2}{|c|}{$\begin{array}{l}\text { Phenolic Content } \\
\quad\left(\mathrm{mg} 100 \mathrm{~g}^{-1}\right)\end{array}$} & \multicolumn{2}{|c|}{$\mathbf{a}^{*}$} & \multicolumn{2}{|c|}{$\mathrm{L}^{*}$} \\
\hline & 8.5 & $\mathrm{c}$ & 8.0 & c & 33.8 & $\mathrm{f}$ & 457.3 & $\mathrm{~d}$ & 36.3 & $\mathrm{~d}$ & 35.5 & $\mathrm{~d}$ \\
\hline $\begin{array}{l}\text { No Solarization } \times 500 \mathrm{~kg} \mathrm{ha}^{-1} \text { of } \\
\qquad \mathrm{CaCN}_{2}\end{array}$ & 9.4 & $\mathrm{a}$ & 8.4 & $\mathrm{~b}$ & 40.3 & $\mathrm{e}$ & 479.2 & c & 42.2 & $\mathrm{a}$ & 40.3 & $\mathrm{~b}$ \\
\hline $\begin{array}{l}\text { No Solarization } \times 1000 \mathrm{~kg} \mathrm{ha}^{-1} \text { of } \\
\qquad \mathrm{CaCN}_{2}\end{array}$ & 9.0 & $\mathrm{~b}$ & 8.8 & a & 51.7 & c & 498.9 & $\mathrm{~b}$ & 35.4 & $\mathrm{~d}$ & 36.6 & d \\
\hline Solarization $\times 0 \mathrm{~kg} \mathrm{ha}^{-1}$ of $\mathrm{CaCN}_{2}$ & 9.1 & $\mathrm{~b}$ & 8.6 & $\mathrm{ab}$ & 47.0 & $\mathrm{~d}$ & 460.9 & $\mathrm{~d}$ & 38.8 & c & 41.2 & $\mathrm{ab}$ \\
\hline Solarization $\times 500 \mathrm{~kg} \mathrm{ha}^{-1}$ of $\mathrm{CaCN}_{2}$ & 9.1 & $\mathrm{~b}$ & 8.9 & $\mathrm{a}$ & 54.5 & $\mathrm{~b}$ & 502.2 & $\mathrm{~b}$ & 40.7 & $\mathrm{~b}$ & 42.2 & $\mathrm{a}$ \\
\hline Solarization $\times 1000 \mathrm{~kg} \mathrm{ha}^{-1}$ of $\mathrm{CaCN}_{2}$ & 9.1 & $\mathrm{~b}$ & 8.6 & $\mathrm{ab}$ & 60.0 & a & 518.2 & $\mathrm{a}$ & 38.7 & c & 38.4 & c \\
\hline \multicolumn{13}{|l|}{ Significance } \\
\hline Solarization & \multicolumn{2}{|c|}{ NS } & \multicolumn{2}{|c|}{$* * *$} & \multicolumn{2}{|c|}{$* * *$} & \multicolumn{2}{|c|}{$* * *$} & \multicolumn{2}{|c|}{$* *$} & \multicolumn{2}{|c|}{$* * *$} \\
\hline Calcium cyanamide $\left(\mathrm{CaCN}_{2}\right)$ & \multicolumn{2}{|c|}{$* *$} & \multicolumn{2}{|c|}{$* * *$} & \multicolumn{2}{|c|}{$* * *$} & \multicolumn{2}{|c|}{$* * *$} & \multicolumn{2}{|c|}{$* * *$} & \multicolumn{2}{|c|}{$* * *$} \\
\hline Solarization $\times \mathrm{CaCN}_{2}$ & \multicolumn{2}{|c|}{ ** } & \multicolumn{2}{|c|}{$* * *$} & \multicolumn{2}{|c|}{ ** } & \multicolumn{2}{|c|}{$* *$} & \multicolumn{2}{|c|}{$* * *$} & \multicolumn{2}{|c|}{$* *$} \\
\hline
\end{tabular}


Strawberry grown on soil exposed to solarization and treated with $500 \mathrm{~kg} \mathrm{ha}^{-1}$ of $\mathrm{CaCN}_{2}$ showed the highest fruit lightness $\left(\mathrm{L}^{*}\right)$, whereas control plants provided the lowest one (Table 3).

Solarization treatments did not significantly affect TA (Table 4).

Table 4. Effect of soil solarization and $\mathrm{CaCN}_{2}$ pre-plant treatment on titratable acidity (TA), $\mathrm{N}$, anthocyanins, antioxidant capacity and $\mathrm{b}^{*}$ of strawberry grown in a protected cultivation system.

\begin{tabular}{|c|c|c|c|c|c|c|c|c|c|}
\hline $\begin{array}{l}\text { Treatments } \\
\text { Solarization }\end{array}$ & \multicolumn{2}{|c|}{$\begin{array}{c}\text { TA (\% of } \\
\text { Citric Acid) }\end{array}$} & \multicolumn{2}{|c|}{$\begin{array}{l}N\left(g 100 g^{-1}\right. \\
\text { of } d w)\end{array}$} & \multicolumn{2}{|c|}{$\begin{array}{l}\text { Anthocyanins (mg of } \\
\text { Cya-3-glucoside per } \\
100 \text { g) }\end{array}$} & \multicolumn{2}{|c|}{$\begin{array}{l}\text { Antioxidant } \\
\text { Capacity } \\
\text { (\% Inhibition) }\end{array}$} & $\mathbf{b}^{*}$ \\
\hline No solarization & 0.4 & & 9.0 & & 99.8 & $\mathrm{~b}$ & 82.1 & $\mathrm{~b}$ & 22.3 \\
\hline Solarization & 0.4 & & 9.2 & & 108.5 & $\mathrm{a}$ & 86.1 & a & 21.7 \\
\hline \multicolumn{10}{|l|}{$\begin{array}{c}\text { Calcium cyanamide } \\
\text { dosage }\left(\mathrm{kg} \mathrm{ha}^{-1}\right)\end{array}$} \\
\hline 0 & 0.5 & a & 9.8 & a & 90.2 & c & 79.1 & $\mathrm{c}$ & 22.0 \\
\hline 500 & 0.4 & $\mathrm{~b}$ & 9.3 & $\mathrm{~b}$ & 108.4 & $\mathrm{~b}$ & 85.1 & $\mathrm{~b}$ & 21.9 \\
\hline 1000 & 0.4 & $\mathrm{~b}$ & 8.2 & c & 114.0 & $\mathrm{a}$ & 88.0 & a & 22.1 \\
\hline \multicolumn{10}{|l|}{ Significance } \\
\hline Solarization & \multicolumn{2}{|c|}{ NS } & \multicolumn{2}{|c|}{ NS } & \multicolumn{2}{|c|}{$* * *$} & \multicolumn{2}{|c|}{$* * *$} & NS \\
\hline $\begin{array}{l}\text { Calcium cyanamide } \\
\qquad\left(\mathrm{CaCN}_{2}\right)\end{array}$ & \multicolumn{2}{|c|}{$* * *$} & \multicolumn{2}{|c|}{$* * *$} & \multicolumn{2}{|c|}{$* * *$} & \multicolumn{2}{|c|}{$* * *$} & NS \\
\hline Solarization $\times \mathrm{CaCN}_{2}$ & \multicolumn{2}{|c|}{ NS } & \multicolumn{2}{|c|}{ NS } & \multicolumn{2}{|c|}{ NS } & \multicolumn{2}{|c|}{ NS } & NS \\
\hline
\end{tabular}

Conversely, the $\mathrm{CaCN}_{2}$ dosage significantly influenced TA, which was highest in fruits from plants grown on plots treated with $0 \mathrm{~kg} \mathrm{ha}^{-1}$ of $\mathrm{CaCN}_{2}$. No significant interaction was found between solarization and $\mathrm{CaCN}_{2}$ dosage in terms of TA.

Without regard of the $\mathrm{CaCN}_{2}$ dosage, solarization treatment did not significantly influence $\mathrm{N}$ fruit concentration (Table 4). Irrespective of the solarization, strawberries from plants grown on soil not exposed to $\mathrm{CaCN}_{2}$ showed the highest $\mathrm{N}$ concentration, followed by those from plants cultivated on plots treated with $500 \mathrm{~kg} \mathrm{ha}^{-1}$ of $\mathrm{CaCN}_{2}$. Plants cultivated in soil treated with a dosage of $1000 \mathrm{~kg}$ $\mathrm{ha}^{-1}$ of $\mathrm{CaCN}_{2}$ had the lowest $\mathrm{N}$ fruit concentration. As regard fruit $\mathrm{N}$ concentration, ANOVA did not display a significant effect of the interaction solarization $\times \mathrm{CaCN}_{2}$.

Anthocyanins fruit content averaged over $\mathrm{CaCN}_{2}$ dosage was significantly higher in plants grown in solarized soil as compared to plants grown in no-solarized plots (Table 4). Fruits from plants grown in soil treated with $1000 \mathrm{~kg} \mathrm{ha}^{-1} \mathrm{CaCN}_{2}$ gave the highest value in terms of anthocyanins content, followed by those harvested from plots treated with $500 \mathrm{~kg} \mathrm{ha}^{-1} \mathrm{CaCN}_{2}$. Fruits from plants grown in soil treated with $0 \mathrm{~kg} \mathrm{ha}^{-1} \mathrm{CaCN}_{2}$ had the lowest anthocyanins content. ANOVA did not show significant effect of the interaction solarization $\times \mathrm{CaCN}_{2}$.

Data collected on antioxidant capacity supported the trend established for anthocyanins content (Table 4).

Treatments tested had no effects on $b^{*}$ color coordinate (Table 4).

\section{Discussion}

Potential use of low environmental impact techniques as replacements or supplements for chemical fungicides have been addressed in many reports [22-24]. A few of these techniques have been tested under field conditions. In this study, the potential use of $\mathrm{CaCN}_{2}$ and soil solarization, alone or combined, to enhance fruit production and quality of strawberry was evaluated. In the present study, a 10-week solarization period was chosen. However, there are reports supporting that shorter solarization periods may be equally effective on strawberry [25]. For example, a six-week solarization treatment consistently lowered the weed density compared to the non-treated control on "Chandler" strawberry 
field crop [26]. Our results showed that improvements in terms of production, vigor and overall fruit quality can be accomplished using the synergistic effect of soil solarization and $\mathrm{CaCN}_{2}$. Our outcomes are consistent with those obtained by $\mathrm{D}^{\prime}$ Anna et al. [3], who, by investigating the effects of solarization with transparent polyethylene (PE) or with green ethylene-vinylacetate (EVA), found that, regardless of the cultivars tested, total marketable fruit yields in solarized plots are significantly higher than in the untreated plots. Our findings are also consistent with those observed by Iapichino et al. [27] who studying the influence of soil solarization and methyl bromide fumigation on the growth and yield of strawberry plants cultivated under plastic tunnel conditions, report that, in the first year, solarization significantly increased both early and total marketable yields by $15 \%$ compared with the fumigated plots, whereas in the successive years, solarization and fumigation were equally effective in increasing yields when compared to untreated plots. Although there are findings that the application of $\mathrm{CaCN}_{2}$ or other stabilized fertilizers containing nitrification inhibitors (NIs) can increase yield in potato (Solanum tuberosum L.) [28], soybean [Glycine max (L.) Merr.] [29], maize (Zea mays L.] [30], and wheat (Triticum aestivum L.) [31]. Hu et al. [32] report that the use of NIs does not significantly influence the yields of several arable crops. Such contrasting results support the hypothesis that the application of NIs may determine a positive yield response only at low $\mathrm{N}$ application rates or when $\mathrm{N}$ is lost by leaching and/or denitrification, causing a level of $\mathrm{N}$ deficiency severe enough to reduce crop yields in absence of NI [33]. However, our study highlighted an increase in yield traits due to an interactive effect solarization $x$ $\mathrm{CaCN}_{2}$ with a dosage of $500 \mathrm{~kg} \mathrm{ha}^{-1} \mathrm{CaCN}_{2}$. Since $\mathrm{CaCN}_{2}$ is transformed to ammonium within a couple of weeks, and, because the ammonium-N may be subject to volatilization, especially in the presence of high temperatures, our positive response of strawberry to the interactive effect solarization and $\mathrm{CaCN}_{2}$ could be related either to species studied or to a right combination timing and dosage of $\mathrm{CaCN}_{2}$ pre-plant application-temperature. Our results on plant growth and vigor are consistent with those of D'Anna et al. [3], who revealed that, regardless of the cultivars tested and in two experimental years, the number of shoots per crown in the solarized plots is significantly higher than in untreated plots. However, our outcomes are in contrast with those of Montemurro et al. [34], who report that the addition of dicyandiamide to urea did not determine an increase of yield in lettuce grown under a protected environment as compared with the simple application of urea. Thus, as reported by Di Gioia et al. [35], it seems that the crop growth response to $\mathrm{N}$ rate and source is the result of a complex interaction between plant genotype and several ecological factors that influence $\mathrm{N}$ availability during the crop season. In our study, quality traits such as fruit skin color and fruit firmness, which are imperative for fruit marketability, were evaluated in regard to pre-plant treatments such as solarization and different doses of $\mathrm{CaCN}_{2}$. According to the scientific literature, fruit color affects the grade and appearance of strawberry as a result of the presence of anthocyanins [36,37]. Strawberry fruit is well known as an excellent source of different antioxidants and secondary metabolites such as ascorbic acid and phenolic compounds [16]. Other authors have found that genotype and cultivation technique have significant effects on the content of the secondary metabolites in strawberry fruits [38-40]. Our results showed that improvement in fruit ascorbic acid, anthocyanins, polyphenol contents, and antioxidant capacity can be accomplished through the combined use of soil solarization and $\mathrm{CaCN}_{2}$ treatment. Considering that several studies have consistently reported the negative effects of high $\mathrm{N}$ applications on nutritional and nutraceutical fruit traits [41-44], we may hypothesize that the higher ascorbic acid, anthocyanins, polyphenols and antioxidant capacity found in strawberry fruits from plots treated with the highest dose of $\mathrm{CaCN}_{2}$ could be due to a slow nitrification process determined by the application of $\mathrm{CaCN}_{2}$ and the persistence of ammonium-N in the soil which may contribute to minimize nutritional stresses derived from the risks of excesses or N deficiency. Our results on TSS and firmness are consistent with those of $\mathrm{D}^{\prime}$ Anna et al. [3], who reveal that, regardless of the cultivars tested in two experimental years, the fruit firmness and TSS detected in untreated plots are significantly lower than in solarized plots. Our outcomes showed that enhancement in fruit firmness can be reached reducing $\mathrm{CaCN}_{2}$ dosage up to $500 \mathrm{~kg} \mathrm{ha}^{-1}$ and combining the $\mathrm{CaCN}_{2}$ treatment with soil solarization. Nitrogen is a basic component of amino acids, proteins, nucleic acids, and quite a lot of other metabolites, which are 
all essential for the growth and development of plants. It is also documented that $\mathrm{CaCN}_{2}$ application affects nitrogen plant availability and accumulation [29]. Our results on $\mathrm{N}$ fruit concentration revealed that a decrease in $\mathrm{N}$ fruit content can be achieved using the highest $\mathrm{CaCN}_{2}$ dosage. Our findings are in line with those of Di Gioia et al. [35], who, by investigating the effects of calcium cyanamide on nitrogen use efficiency (NUE), yield, nitrates, and dry matter content of lettuce, found that $\mathrm{CaCN}_{2}$ may be used to enhance lettuce quality by reducing $\mathrm{NO}_{3}{ }^{-}$accumulation. Our outcomes are also consistent with those of Montemurro et al. [34] and Richardson and Hardgrave [45], who report that the application of NIs can reduce $\mathrm{NO}_{3}{ }^{-}$accumulation in lettuce.

\section{Conclusions}

In the present study, soil solarization combined with $\mathrm{CaCN}_{2}$ treatment significantly influenced yield traits, plant vigor, and nutritional and nutraceutical properties in strawberry fruits. Combining solarization with 500 or $1000 \mathrm{~kg} \mathrm{ha}^{-1} \mathrm{CaCN}_{2}$ effectively promoted production performance and plant vigor as well as the accumulation of TSS and some antioxidant fruit compounds such as polyphenols, anthocyanins, ascorbic acid, and antioxidant capacity as compared with the control. Our results also showed that the solarization or the $\mathrm{CaCN}_{2}$ treatments were not detrimental to strawberry plants. Finally, due to the significant interactions solarization $\times \mathrm{CaCN}_{2}$ dosage, this study showed that, for each soil pre-plant treatment tested (solarized or no-solarized), there is an optimal $\mathrm{CaCN}_{2}$ dosage such that optimal levels of yield and overall fruit quality may be achieved. Nevertheless, our findings suggest that a combination of solarization and a $\mathrm{CaCN}_{2}$ treatment at 500 or $1000 \mathrm{~kg} \mathrm{ha}^{-2}$ may effectively improve crop performance and fruit nutritional and nutraceutical quality of strawberry.

Author Contributions: Conceptualization, L.S., F.D., and G.I.; Data curation, L.S.; Formal analysis, L.S.; Investigation, L.S. and C.P.; Methodology, L.S., F.D. and G.I.; Supervision, G.I.; Writing-original draft, L.S.; Writing-review and editing, L.S. and G.I.

Funding: This research received no external funding.

Conflicts of Interest: The authors declare no conflict of interest.

\section{References}

1. Biswas, M.K.; Islam, R.; Hossain, M. Micropropagation and field evaluation of strawberry in Bangladesh. J. Agric. Tech. 2008, 4, 167-182.

2. D'Anna, F.; Caracciolo, G.; Moncada, A.; Prinzivalli, C.; Palermo, M.L.; Amato, F.; Angileri, G.; Fici, G.; Mezzapelle, V.; Signorino, G. Alternatives to methylbromide in strawberry cultivation. Acta Hortic. 2009, 807, 745-750. [CrossRef]

3. D'Anna, F.; Iapichino, G.; D'Anna, E. Effects of soil solarization with different plastic films on yield performance of strawberry protected plantations in Sicily. Acta Hortic. 2014, 1015, 53-58. [CrossRef]

4. Hannum, S.M. Potential impact of strawberries on human health: A review of the science. Crit. Rev. Food SciNutr. 2004, 44, 1-17. [CrossRef] [PubMed]

5. Zhen, W.C.; Cao, K.Q.; Dai, L.; Hu, T.L. Management of strawberry (Fragria ananassa Duch) replanting problem by soil amendments of medicinal herbs. Sci. Agric. Sin. 2005, 38, 730-735. (In Chinese)

6. UNEP (United Nations Environment Programme). Handbook for the Montreal Protocol on Substance that Deplete the Ozone Layer; Secretariat of The Vienna Convention for the Protection of the Ozone Layer \& The Montreal Protocol on Substances that Deplete the Ozone Layer: Nairobi, Kenya, 2006.

7. Medina-Minguez, J.J. Soil solarization and biofumigation in strawberries in Spain. In Proceedings of the International Conference on Alternatives to Methyl Bromide, Sevilla, Spain, 5-8 March 2002; pp. 123-125.

8. Pullman, G.S.; DeVay, J.E.; Garber, R.H. Soil solarization and thermal death: A logarithmic relationship between time and temperature for four soilborne plant pathogens. Phytopathology 1981, 71, 959-964. [CrossRef]

9. Ciancio, A.; Mukerji, K.G. Integrated Management of Plant Pests and Diseases; Springer science+Business Media, B.V.: Berlin, Germany, 2009; p. 346. 
10. Davino, S.; Panno, S.; Iacono, G.; Sabatino, L.; D'Anna, F.; Iapichino, G.; Olmos, A.; Scuderia, G.; Rubio, L.; Tomassoli, L.; et al. Genetic variation and evolutionary analysis of Pepino mosaic virus in Sicily: Insights into the dispersion and epidemiology. Plant Pathol. 2017, 66, 368-375. [CrossRef]

11. Ling, K.S. Effectiveness of Chemo- and Thermotherapeutic Treatments on Pepino mosaic virus in Tomato Seed. Plant Dis. 2010, 94, 325-328. [CrossRef]

12. Kodama, T.; Fukai, T. Solar heating in closed plastic house for control of soil-borne diseases. V. Application for control of Fusarium wilt of strawberry. Ann. Phytopat. Soc. Japn. 1982, 48, 570-577. [CrossRef]

13. Lijing, W.; Tongle, H.U.; Lijing, J.I.; Keqiang, C. Inhibitory efficacy of calcium cyanamide on the pathogens of replant diseases in strawberry. Front. Agric. China 2007, 1, 183-187.

14. Bletsos, F.A. Use of grafting and calcium cyanamide as alternatives to methyl bromide soil fumigation and their effects on growth, yield, quality and fusarium wilt control in melon. J. Phytopathol. 2005, 153, 155-161. [CrossRef]

15. Zhu, B.L.; Ma, J.W.; Ye, X.Z.; Xia, Z.M. Effects of lime-nitrogen on soil ameliorate and vegetables production. J. Zhejiang Univ. (Agric. Life Sci.) 2001, 27, 339-342. (In Chinese)

16. Sabatino, L.; De Pasquale, C.; Aboud, F.; Martinelli, F.; Busconi, M.; D'Anna, E.; Panno, S.; Iapichino, G.; D'Anna, F. Properties of new strawberry lines compared with well-known cultivars in winter planting system conditions. Not. Bot. HortiAgrobo. 2017, 45, 9-16. [CrossRef]

17. Han, C.; Zhao, Y.; Leonard, S.W.; Traber, M. Edible coatings to improve storability and enhance nutritional value of fresh and frozen strawberries (Fragaria $\times$ ananassa) and raspberries (Rubus ideaus). Postharvest Biol. Technol. 2004, 33, 67-78. [CrossRef]

18. Slinkard, K.; Singleton, V.L. Total phenol analysis: Automation and comparison with manual methods. AJEV 1997, 28, 49-55.

19. Rabino, I.; Mancinell, A. Light, temperature, and anthocyanins production. J. Plant Physiol. 1986, 81, 922-924. [CrossRef] [PubMed]

20. Brand-Williams, W.; Cuvelier, M.E.; Berset, C. Use of a Free Radical Method to Evaluate Antioxidant Activity. Lebenson. Wiss. Technol. 1995, 28, 25-30. [CrossRef]

21. Sorrenti, V.; Salerno, L.; Di Giacomo, C.; Acquaviva, R.; Siracusa, M.A.; Vanella, A. Imidazole derivatives as antioxidants and selective inhibitors of nNOS. Nitric Oxide 2006, 14, 45-50. [CrossRef]

22. Gams, W.; Bissett, J. Morphology and Identification of Trichoderma. In Trichoderma and Gliocladium: Basic Biology, Taxonomy and Genetics; Kubicek, C.P., Harman, G.E., Eds.; Taylor and Francis: London, UK, 1998; pp. 3-34.

23. Washington, W.S.; Engleitner, S.; Boontjes, G.; Shanmuganathan, N. Effect of fungicides, eaweed extracts, tea tree oil, and fungal agents on fruit rot and yield in strawberry. Aust. J. Exp. Agric. 1999, 39, 487-494. [CrossRef]

24. Howell, C.R. Relevance of mycoparasitism in the biological control of Rhizoctoniasolaniby Gliocladiumvirens. Phytopathology 1987, 77, 992-994. [CrossRef]

25. Gamliel, A.; Katan, J. Soil Solarization: Theory and Practice; The American Phytopathological Society (APS): St. Paul, MN, USA, 2012; p. 266.

26. Samtani, J.B.; Derr, J.; Conway, M.A.; Flanagan, R.D. Evaluating soil solarization for weed control and strawberry (Fragaria $\times$ ananassa) yield in annual plasticulture production. Weed Technol. 2017, 31, 455-463. [CrossRef]

27. Iapichino, G.; Prinzivalli, C.; D’Anna, F. Soil Solarization as an Alternative to Methyl Bromide Fumigation for Annual Strawberry Production in a Mediterranean Area. J. Sustain. Agric. 2008, 32, 365-375. [CrossRef]

28. Kelling, K.A.; Wolkowski, R.P.; Ruark, M.D. Potato response to nitrogen form and nitrification inhibitors. Am. J. Potato Res. 2011, 88, 459-469. [CrossRef]

29. Kaushal, T.; Onda, M.; Ito, S.; Yamazaki, A.; Fujikake, H.; Ohtake, N.; Sueyoshi, K.; Takahashi, Y.; Ohyama, T. Effect of deep placement of slow-release fertilizer (lime nitrogen) applied at different rates on growth, N2 fixation and yield of soya bean (Glycine max L. Merr.). J. Agron. Crop. Sci. 2006, 192, 417-426. [CrossRef]

30. Ball-Coelho, B.R.; Roy, R.C. Enhanced ammonium sources to reduce nitrate leaching. Nutr. Cycl. Agroecosyst. 1999, 54, 73-80. [CrossRef]

31. Sharma, S.N.; Kumar, R. Effects of dicyandiamide (DCD) blended with urea on growth, yield and nutrient uptake of wheat. J. Agric. Sci. 1998, 131, 389-394. [CrossRef] 
32. Hu, Y.; Schraml, M.; von Tucher, S.; Li, F.; Schmidhalter, U. Influence of nitrification inhibitors on yields of arable crops: A meta-analysis of recent studies in Germany. Int. J. Plant Prod. 2014, 8, 33-50.

33. Frye, W. Nitrification inhibition for $\mathrm{N}$ efficiency and environment protection. In Proceedings of the IFA International Workshop on Enhanced-Efficiency Fertilizers, Frankfurt, Germany, 28-30 June 2005; IFA: Paris, France, 2005; pp. 1-8.

34. Montemurro, F.; Capotorti, G.; Lacertosa, G.; Palazzo, D. Effects of urease and nitrification inhibitors application on urea fate in soil and nitrate accumulation in lettuce. J. Plant Nutr. 1998, 21, 245-252. [CrossRef]

35. Di Gioia, F.; Gonnella, M.; Buono, V.; Ayala, O.; Cacchiarelli, J.; Santamaria, P. Calcium Cyanamide Effects on Nitrogen Use Efficiency, Yield, Nitrates, and Dry Matter Content of Lettuce. Agron. J. 2017, 109, 354-362. [CrossRef]

36. Zabetakis, I.; Delphine, L.; Kajda, P. Effect of high hydrostatic pressure on the strawberry anthocyanins. J. Agric. Food Chem. 2000, 48, 2749-2754. [CrossRef]

37. Patras, A.; Brunton, N.P.; Da Pieve, S.; Butler, F. Impact of high pressure processing on total antioxidant activity, phenolic, ascorbic acid, anthocyanin content and colour of strawberry and blackberry purées. IFSET 2009, 10, 308-313. [CrossRef]

38. Bianchi, G.; Lucchi, P.; Maltoni, L.; Fagherazzi, A.F.; Baruzzi, G. Analysis of aroma compounds in new strawberry advanced genotypes. Acta Hortic. 2017, 1156, 673-678. [CrossRef]

39. Cocco, C.; Magnani, S.; Maltoni, M.L.; Quacquarelli, I.; Cacchi, M.; Antunes, L.E.C.; D'antuono, L.F.; Faedi, W.; Baruzzi, G. Effects of site and genotype on strawberry fruits quality traits and bioactive compounds. J. Berry Res. 2015, 5, 145-155. [CrossRef]

40. D’Anna, F.; Caracciolo, G.; Parrinello, A.; Baruzzi, G. Effects of Pre-Plant soil treatments on strawberry in sicily. Acta Hortic. 2014, 1049, 929-932. [CrossRef]

41. Mercelle, R.D. Mineral nutrition and fruit quality. Acta Hortic. 1995, 383, 219-226. [CrossRef]

42. Neilsen, G.H.; Neilsen, D.; Herbert, L. Nitrogen fertigation concentration and timing of application affect nitrogen nutrition, yield, firmness, and color of apples grown at high density. HortScience 2009, 44, 1425-1431. [CrossRef]

43. Tahir, I.I.; Johansson, E.; Olsson, M.E. Improving the productivity, quality, and storability of 'Katja' apple by better orchard management procedures. HortScience 2008, 43, 725-729. [CrossRef]

44. Stefanelli, D.; Goodwin, I.; Jones, R. Minimal nitrogen and water use in horticulture: Effects on quality and content of selected nutrients. Food Res. Int. 2010, 43, 1833-1843. [CrossRef]

45. Richardson, S.J.; Hardgrave, M. Effect of temperature, carbon dioxide enrichment, nitrogen form and rate of nitrogen fertilizer on the yield and nitrate content of two varieties of glasshouse lettuce. J. Sci. Food Agric. 1992, 59, 345-349. [CrossRef]

(C) 2019 by the authors. Licensee MDPI, Basel, Switzerland. This article is an open access article distributed under the terms and conditions of the Creative Commons Attribution (CC BY) license (http://creativecommons.org/licenses/by/4.0/). 